\title{
非極性溶媒中におけるカルボン酸と酸素窒素原子上の 孤立電子対との相互作用
}

\author{
平田博文*.今枝健一・田中 洋・福住一雄 \\ 名古屋大学工学部応用化学教室 (名古屋市千種区不老町) \\ * 工業技術院東京工業試験所 (東京都啮谷区本町 1-1-5)
}

\author{
Interactions of Carboxylic Acid with Lone Pair of Oxygen and/or \\ Nitrogen Atom in Molecules in Nonpolar Aprotic Solvents \\ Hirohumi Hirata*, Ken-ichi Imaeda, Hiroshi Tanaka and Kazuo Funuzumi \\ Department of Applied Chemistry, Faculty of Engineering, Nagoya University \\ (Furo-cho, Chikusa-ku, Nagoya-shi) \\ * National Chemical Laboratory for Industry \\ (1-chome, Honmachi,[Shibuya-ku, Tokyo)
}

The rate of acetic acid catalyzed elimination reaction of 1-( $m$-nitrophenyl)-2-(2-quinolyl) ethyl acetate $\left[1_{m}\right]$ to give trans-2-(m-nitrostyryl) quinoline $[2 m]$ is correlated with the electron donability of solvents, $\Delta \nu_{D}$, rather than with the dilectric constant of solvents, $D$, because of hydrogen bonding complex between acetic acid and solvent.

Addition of solvents having lone pair of oxygen and/or nitrogen atom (nitrile, carbonyl, ether, alcohol, amide, sulphoxide or amine) caused a decrease in rate for the dichloroacetic acid catalyzed elimination of $\left[1_{m}\right]$ in benzene at $40^{\circ} \mathrm{C}$. From the drop in rate, the equilibrium constant $K$ of the formation of hydrogen bonding complex between dichloroacetic acid and lone pair of oxygen and/or nitrogen atom in benzene was estimated. A good linear free energy relation was observed between the equilibrium constant $K$ and the electron donability of solvents, SX, which is very important. From the above linear correlation, it is found that the basicity of oxygen atom of alcohols is as strong as that of dioxane (or ethers). A molecule of a strong amine (e.g., triethyl amine) interacted with more than one molecule of dichloroacetic acid in benzene or in toluene at $40^{\circ} \mathrm{C}$, which suggests a $1: 2$ complex.

\section{1 緒 言}

最近, 著者は 1-(m-ニトロフェニル)-2-(キノリル) エチルアセタート $\left[1_{m}\right]$ の脱離反応がカルボン酸触媒存 在下で容易に起こり, trans-2-(m-ニトロスチリル) キ

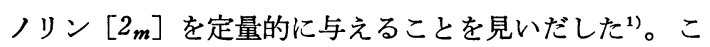
の脱離反応の酢酸触媒存在下に抢ける溶媒効果について

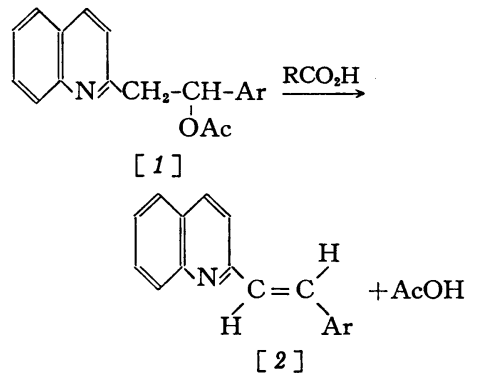

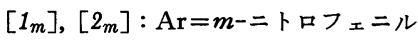

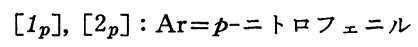

検討したところ, 見かけの 1 次速度定数の対数直は溶媒 の誘電率 $D$ よりはむしろ溶媒の電子供与度 $\Delta \nu_{D}{ }^{2)}$ と良 好な負の相関性があることがわかった。さらに, ベンゼ ン溶媒中ジク口ロ酶酸存在下で酸素や窒素原子をもつ溶 媒分子を添加すると式 (1) の反応速度が低下することが わかった。この速度低下からカルボン酸と酸素, 窒素原 子上の孤立電子対との相互作用について検討した。

\section{2 実験}

\section{$2 \cdot 1$ 溶媒および原料}

溶媒は常法 ${ }^{10}$ によって精製した。アミン類は水酸化力 リウムで脱水, 乾燥後窒素気流下で蒸留した。酢酸は文 献 ${ }^{10)}$ によって精製 (bp $\left.118^{\circ} \mathrm{C}\right)$ し，ジクロロ酢酸は窒素 気流下で減圧蒸留 $\left(\mathrm{bp}_{24} 100^{\circ} \mathrm{C}\right)$ した。 $m$-ニトロベンズ 


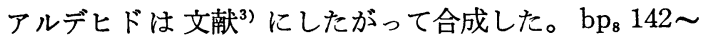
$144^{\circ} \mathrm{C}$ 。

\section{$2 \cdot 2$ 生 成物}

$2 \cdot 2 \cdot 1 \quad 1-(m-$ ニトロフェニル)-2-(2-キノリル) エタ ノール

$p$-ニトロ体と同様の方法4) で合成した。収率 $50 \%$ ， mp $155 \sim 157^{\circ} \mathrm{C}, \quad \mathrm{IR}(\mathrm{KBr}) ; 3270 \mathrm{~cm}^{-1}\left(\nu_{\mathrm{OH}}\right), \quad \mathrm{NMR}$ $\left(\mathrm{CDCl}_{3}\right) ; \delta(\mathrm{ppm}) 3.35\left(\mathrm{CH}_{2}, d\right) 5.40(\mathrm{CH}, t) 7.1 \sim 8.4$ (芳香族プロトン, $\mathrm{OH}$ )

$$
\begin{aligned}
& 2 \cdot 2 \cdot 2 \quad 1-(m-\text { ニトロフェニル)-2-(2-キノリル) エチ } \\
& \text { ルアセタート }\left[1_{m}\right]
\end{aligned}
$$

$\left[1_{p}\right]$ の場合4) と同じ方法で合成した。収率 $70 \%$ 以上, $\mathrm{mp} 105 \sim 106^{\circ} \mathrm{C}, \mathrm{IR}(\mathrm{KBr}) ; 1,735 \mathrm{~cm}^{-1}\left(\nu_{\mathrm{C}=\mathrm{O}}\right)$, NMR $\left(\mathrm{CDCl}_{3}\right) ; \delta(\mathrm{ppm}) 2.00\left(\mathrm{CH}_{3}, s\right) 3.48\left(\mathrm{CH}_{2}, d\right) 6.41$ $(\mathrm{CH}, t) 7.1 \sim 8.4$ (芳香族プロトン)。

$2 \cdot 2 \cdot 3$ trans-2-(m-ニトロスチリル $)$ キノリン $[2 m]$ $\left[2_{p}\right]$ とほぼ同じ方法で合成した ${ }^{4)} 。 \operatorname{mp~} 155^{\circ} \mathrm{C}, \mathrm{IR}$ $(\mathrm{KBr}) ; 966 \sim 976 \mathrm{~cm}^{-1}\left(\nu_{\text {trans }}-\mathrm{CH}=\mathrm{CH}_{-}\right), \mathrm{UV}(0.1 \mathrm{~mol} /$ $\left.l \mathrm{HCl} / \mathrm{CH}_{3} \mathrm{OH}\right) ; \lambda_{\max } 361 \mathrm{~m} \mu \log \varepsilon 4.59$ 。

\section{$2 \cdot 3$ 反応速度測定法}

反応速度は適当な時間間隔ごとにピペットで反応液を とり出し, $0.1 \mathrm{~mol} / l$ の塩酸を含むメタノールで希釈し, 紫外分光光度法で 生成した trans-オレフィン $\left[2_{m}\right]$ の 極大吸収 ( $\left.\lambda_{\max } 361 \mathrm{~m} \mu\right)$ を追跡して求めた。見かけの 1 次速度定数 $k_{1, a}$ は $\log (a-x) v s . t$ (時間) のプロッ トの傾きから計算した。ここで, $a$ は $\left[1_{m}\right]$ の初濃度, $x$ は時間 $t$ のときの $\left[2_{m}\right]$ の濃度である。生成物 の trans-オレフィン $[2]$ のメタノール希釈液は塩酸の存 在の有無にかかわらず室内の光によって容易に $\lambda_{\max }$ が 低波長に移動しかつ $\varepsilon$ も小さなるため注1), 反応はか っ色容器中で行い, かつ, 反応操作, 希釈操作および分 光器による測定は暗室中で行った。また, 反応希釈液は 光をしゃ断するためアルミはくで包装した試験管の中に 保存した。

注 1）とのシフトは $\pi-\pi^{*}$ 遷移による trans-cis 光異性化 反応による。

\section{3 結果と考察}

3.1 酢酸触媒による 1-(m-ニトロフェニル)-2-(2キノリル）エチルアセタート $\left[1_{m}\right]$ の脱離反応の 溶媒効果

酶酸による $\left[1_{m}\right]$ の脱離反応を 19 種の溶媒を用い て, $30^{\circ} \mathrm{C}$ で速度論的に検討した。結果は Table-1 に示 す通りである。この表の見かけの 1 次速度定数 $k_{1, a}$ は 次式によって求めた值である。ここで, $a$ は $\left[1_{m}\right]$ の初 濃度, $x$ は時間 $t$ のときの $[2 m]$ の濃度である。

$$
v=k_{1, a}(a-x) \text {. }
$$

まず溶媒効果の様子を調べるため, 溶媒の誘電率 $D$ との相関性について調べた。Fig.-1 に $\log k_{1, a}$ vs. $D$
のプロットを示した。この図からわかるように， $\left[1_{m}\right]$ の脱離の反応速度 は全体として負の相関性, つまり $D$ が大きくなるにつれて速度が低下することがわかるが, あまり良い相関性とはいえない。しかし，溶媒の種類に よって分けると次のようにいえる。(1) 炭化水素溶媒の 場合 : $n$-ヘキサン, $n$-ヘプタン<シクロヘキサン>クロ ロホルムの順である, つまり, 溶媒の誘電率 $D$ の増加に 伴って速度が極大を示す位置が存在する。(2) 芳香族炭 化水素溶媒の場合 : ベンゼン<トルエン<o-ジクロロベ ンゼン>クロロベンゼンであり, 炭水化水素溶媒の場合 と同様, 極大位置をもつ。(3) アルコール溶媒の場合 : $n$-プロパノール>エタノール>メタノールの順, つまり 誘電率の増加とともに反応速度が低下する。(4) カルボ ニル基をもつ溶媒の場合：眽酸エチル>アセトン $>\mathrm{N}$, N-ジメチルホルムアミドの順となり，アルコール溶媒 の場合と同様, 誘電率の増加とともに反応速度が低下す る。(5) エーテル溶媒の場合 : ジオキサン>テトラヒド ロフラン, この場合も誘電率が増加すると速度が低下す る。(6) 無水酩酸, アセトニトリル, ジメチルスルホキ シドは上記の分類から除外した。(7) 各溶媒の分類別の 反応性は, 炭化水素>芳香族炭化水素>カルボニル基を もつ溶媒>エーテルの順である。

Table-1 Solvent effect on the acetic acid catalyzed elimination of 1-( $m$-nitrophenyl)-2-(2quinolyl)ethyl acetate $\left[1_{m}\right]^{1), 2)}$.

\begin{tabular}{r|l|r|r|r}
\hline No. & \multicolumn{1}{|c|}{ Solvent } & $10^{5} k_{1}, a^{8)}$ & \multicolumn{1}{c|}{$D^{4)}$} & $\Delta \nu_{D}{ }^{5)}$ \\
\hline 1 & Cyclohexane & 13.3 & 2.02 & - \\
2 & $n$-Hexane & 11.5 & 1.90 & 1 \\
3 & $o$-Dichlorobenzene & 11.3 & 3.03 & -11 \\
4 & $n$-Heptane & 11.3 & 1.93 & 0 \\
5 & Chlorobenzene & 9.89 & 5.62 & -2 \\
6 & Toluene & 9.30 & 2.64 & 2 \\
7 & Benzene & 9.01 & 2.27 & 0 \\
8 & Chloroform & 8.74 & 4.81 & -17 \\
9 & Acetic anhydride & 5.94 & 20.7 & - \\
10 & $n$-Propanol & 4.03 & 19.7 & - \\
11 & Acetonitrile & 3.68 & 37.5 & 49 \\
12 & Ethanol & 3.16 & 24.3 & - \\
13 & Ethyl acetate & 2.84 & 6.03 & 39 \\
14 & Methanol & 2.43 & 32.6 & - \\
15 & Acetone & 1.50 & 20.5 & 64 \\
16 & Dioxane & 1.00 & 2.21 & 77 \\
17 & Dimethyl sulfoxide & 1.00 & 48.9 & 141 \\
18 & Tetrahydrofuran & 0.80 & 7.39 & 90 \\
19 & N, N-Dimethylformamide & 0.70 & 36.7 & 107 \\
\hline 1 & Reaction temperature & & &
\end{tabular}

1) Reaction temperature; $30^{\circ} \mathrm{C}$

2) Initial concentrations; Acetic acid $0.803 \mathrm{~mol} / l,\left[1_{m}\right]$ $3 \sim 6 \times 10^{-4} \mathrm{~mol} / l$.

3) The apparent first order rate constant in $\sec ^{-1}$ with regard to acetate $\left[1_{m}\right]$.

4) Dielectric constant of solvents ${ }^{5)}$

5) The electron donability in $\mathrm{cm}^{-1,2)}$ 


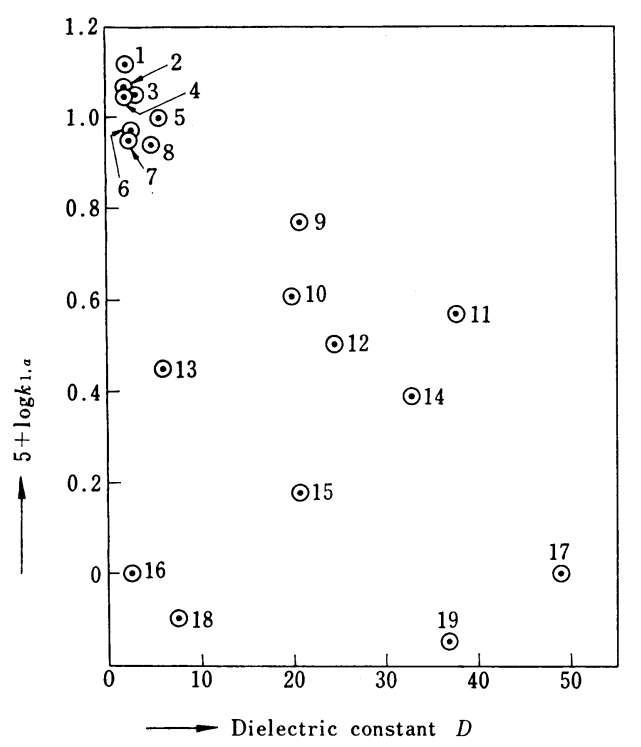

From the data in Table-1.

Solvents; $1:$ Cyclohexane, $2: n$-Hexane, $3: o$-Dichlorobenzene, $4: n$-Heptane, $5:$ Chlorobenzene, $6:$ Toluene, $7:$ Benzene, $8:$ Chloroform, $9:$ Acetic anhydride, 10 : $n$-Propanol, $11:$ Acetonitrile, $12:$ Ethanol, $13:$ Ethyl acetate, $14:$ Methanol, $15:$ Acetone, $16:$ Dioxane, 17 : Dimethyl sulfoxide, $18:$ Tetrahydrofuran, $19: \mathrm{N}, \mathrm{N}-$ Dimethyl formamide.

Fig.-1 A plot of $\log k_{1, a}$ vs. $D$ (dielectric constant) for the acetic acid catalyzed elimination reaction of $\left[1_{m}\right]$ at $30^{\circ} \mathrm{C}$.

最近, 著者はベンゼン溶媒中の 1 - ( $p$-ニトロフェニ ル)-2-(2-キノリル) エチルアセタート $\left[1_{p}\right]$ のカルボ ン酸による脱離反応の速度論的研究 $\left(40^{\circ} \mathrm{C}\right)$ から反応が つぎの機構 (Scheme-1) で進むことを報告した ${ }^{4)}$ 。

Scheme-1

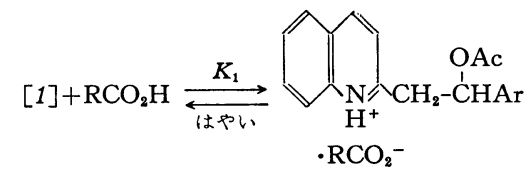

$$
K_{1}: \text { 平衡定数 }
$$

$k: 1$ 次速度定数

すなわち, カルボン酸がアセタート $\left[1_{p}\right]$ のキノリン窒 素にプロトン化してイオン対（第四級塩）［3］を生成 し, このイオン対の対陰イオン, カルボシラートアニ オンが $\beta$-水素を $\mathrm{E} 2$ 型で攻撃して trans-オレフィン $[2 \boldsymbol{p}]$ を生ずる。ここで, 最初のプロトン化の段階がは やく, 特殊酸触媒 (Brönsted の $\alpha$ 值 >0.93) で起こ り, カルボキシラートアニオンの $\beta$-水素攻撃が律速で, 一般塩基触媒 (Brönsted $の \beta$ 值 0.2 ) で起こる。全体 で一般酸触媒 $\left(k K_{1}\right.$ の Brönsted の $\alpha$ 值 0.78) で起こ
る。

ここで， $\left[1_{m}\right]$ の酢酸による脱離の反応速度と溶媒の 誘電率 $D$ との関係 (Fig.-1) についてみると, 全体と してほぼ負の相関性を示すことから，この脱離反応はイ オン対 (第四級塩) [3] を経て起こると結論できる。 非極性非 プロトン溶媒（炭化水素および芳香族炭化水 素）の場合，ベンゼン中の $\left[1_{p}\right]$ の脱離と全く同じであ ると考えられる。これらの溶媒中の場合, 溶媒の誘電率 $D$ が大きくなると $K_{1}$ 沙ささくり,$k$ は大きくなる。 全体の反応は $k K_{1}$ に比例するから， $k$ と $K_{1}$ の相反 する効果のため誘電率に対して極大をもつ（Table-1, Fig.-1)。また, これらの溶媒中では, 酢酸は二量体と 単量体 (あるいは $\mathrm{CH}_{3} \mathrm{CO}_{2} \mathrm{H} \cdots \pi$ ) の平衡混合物として 存在し ${ }^{6)}$, その酸度の強さは単量体 $\left(2 \mathrm{CH}_{3} \mathrm{CO}_{2} \mathrm{H} \cdots \pi\right)$ $>$ 二量体となり, しかもその濃度も反応性に関与すると 思われる。詳細については現在検討中である。他の溶媒 （アルコール, カルボニル, エーテル）の場合, $D$ が増 加すると反応速度が低下している。このことはこれらの 溶媒中の反応もイオン対 [3] を経て起こることを示唆し ている。非極性非プロトン溶媒の場合とちがって極大を もたないのは, これらの溶媒中では $k$ が反応に大きく 関与するためであろう。

誘電率 $D$ が約 2 の溶媒についてその反応性について 比較すると, シクロヘキサン>ベンゼン》ジオキサンの 順である。このことは酢酸の反応種として酢酸と溶媒の 塩基性の部分とが相互作用（水素結合）した形であるこ とを示唆している。そこで， $\left[1_{m}\right]$ の脱離反応の速度と 溶媒の電子与度 $\Delta \nu_{D}{ }^{2)}$ との相関性について調べた。結果 は Fig.-2 $\left(\log k_{1, a}\right.$ vs. $\left.\Delta \nu_{D}\right)$ に示した。この図からわ かるように, 溶媒の電子供与度との相関性は, 誘電率と の場合 (Fig.-1) とは異なりかなり良好な負の相関性を 示す。このことは, 酢酸の反応種として, 酢酸と溶媒 分子の孤立電子対との水素結合錯体であることを支持す る。溶媒の電子供与度 $\Delta \nu_{D}\left(\mathrm{~cm}^{-1}\right)$ は, メタノール-O-d の OD の IR 吸収のシフト值 (ベンゼン中 $\Delta \nu_{D}=0$ ) で あるから ${ }^{2)}$, この值は溶媒分子の孤立電子対とメタノー ル-O-d との水素結合のしやすさの 尺度である。した がって, 電子供与性の高い溶媒中ではそれだけ強く酢酸 と溶媒分子とが水素結合するため酢酸の酸度が低下して $\left[1_{m}\right]$ の脱離速度が低下する (Fig.-2)。前述のように， プロトン化の段階が特殊酸触媒であることよりカルボン 酸の酸度が $\left[1_{m}\right]$ の脱離に大きく効く, つまり $K_{1}$ の 項に大きく効くはずであり， $\Delta \nu_{D}$ と良好な負の相関性を 示すことは $\left[1_{m}\right]$ の脱離が Scheme-1 で起こっている ことを支持する。

$\mathrm{N}, \mathrm{N}$-ジメチルホルムアミドやジメチルスルホキシド 溶媒中では緊密イオン対のほかに溶媒介在イオン対の存 在が知られており ${ }^{7)},\left[1_{m}\right]$ の脱離反応の速度は, ジメ 


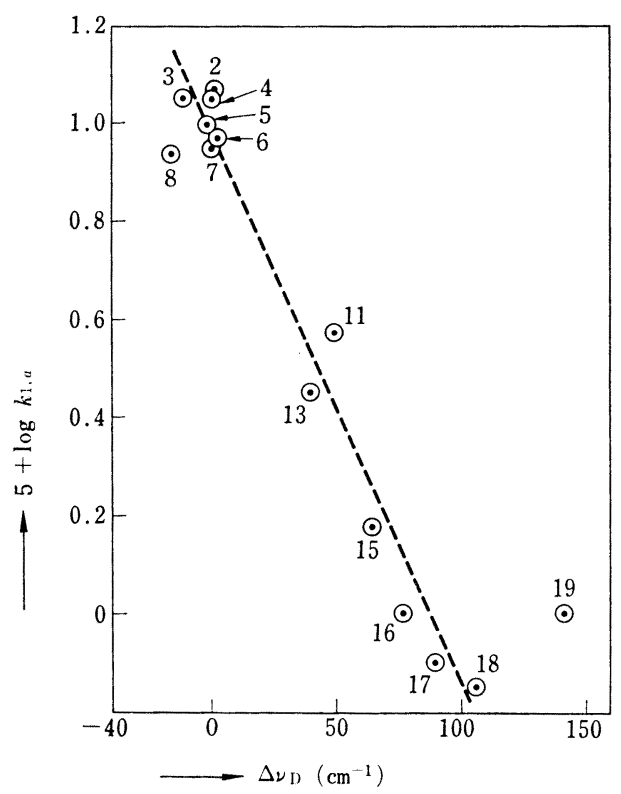

From the data in Table-1.

Solvents; $2: n$-Hexane, $3: o$-Dichlorobenzene, $4: n$ Heptane, $5:$ Chlorobenzene, $6:$ Toluene, $7:$ Benzene, 8: Chloroform, $11:$ Acetonitrile, $13:$ Ethyl acetate, $15:$ Acetone, $16:$ Dioxane, $17:$ Dimethyl sulfoxide, 18 : Tetrahydrofuran, $19: \mathrm{N}, \mathrm{N}$-Dimethylformamide.

Fig.-2 A plot of $\log k_{1, a}$ vs. $\Delta \nu_{D}$ (the electron donability) for the acetic acid catalyzed elimination reaction of $[1 \mathrm{~m}]$ at $30^{\circ} \mathrm{C}$.

チルスルホキシドの場合電子供与度の值から予想される よりもいくらか反応が早いことからその可能性が考えら れる。しかし，これだけの結果から，その存在を結論す ることは困難である。

\section{$3 \cdot 2$ ベンゼン溶媒中におけるジクロロ酢酸と溶媒分}

子の酸素, 窒素原子上の孤立電子対との相互作用 (水素結合錯体)

$\left[1_{m}\right]$ の酢酸による脱離の反応速度が溶媒の電子供与 度 $\Delta \nu_{D}$ と良好な負の相関性 (Fig.-2) があり，それは 酢酸と溶媒分子上の孤立電子対との水素結合錯体による ものであることがわかった。しかし, Table-1 の脱離反 応では酢酸の二量体の関与や溶媒の効果が含まれるため 純粋な水素結合錯体に関する知見は得られにくい。そこ で, ベンゼン溶媒中 $40^{\circ} \mathrm{C}$ でジクロ口酢酸触媒存在下で 酸素や窒素原子（孤立電子対）をもつ溶媒分子が $\left[1_{m}\right]$ の脱離反応に及ぼす効果について検討した。結果は Table-2 に示した。この実験では，ジクロ口酢酸は 〜 10-3 mol/l であるから二量体の関与は無視できる。 見かけの 1 次速度定数は式 (2) によって求めた。この表 から孤立電子対をもつ溶媒分子を添加すると反応速度が 低下することがわかる。この速度低下から，水素結合錯 体生成の平衡定数 $K$ を下記の方法で図式的 (Fig.-3)
Table-2 The effect of added solvents, SX, on the dichloroacetic acid catalyzed elimination of $\left[1_{m}\right]$ in benzene at $40^{\circ} \mathrm{C}^{4}$.

\begin{tabular}{|c|c|c|c|c|c|}
\hline No. & $\begin{array}{l}\text { Added solvent SX } \\
\text { (Electron } \\
\text { donability, } \mathrm{cm}^{-1} \text { ) }\end{array}$ & \begin{tabular}{|}
$\begin{array}{c}\text { Initial con- } \\
\text { centration } \\
\text { of SX } \\
(\mathrm{mol} / l)\end{array}$ \\
\end{tabular} & \begin{tabular}{|c|} 
Rate \\
constant 1$)$ \\
$10^{4} k_{1}, a$ \\
$\left(\sec ^{-1}\right)$ \\
\end{tabular} & \multicolumn{2}{|c|}{$\left.\log K^{2}\right\}$ av. } \\
\hline 1 & $\begin{array}{l}\text { Anisol } \\
\text { (26) }\end{array}$ & $\begin{array}{l}0.82 \times 10^{-1} \\
1.63 \\
2.45 \\
3.27 \\
4.08\end{array}$ & $\begin{array}{l}5.03 \\
4.68 \\
4.57 \\
4.38 \\
4.21\end{array}$ & $\left.\begin{array}{l}-0.08 \\
-0.05 \\
+0.04 \\
-0.06 \\
-0.06\end{array}\right\}$ & $-0.04 \pm 0.08$ \\
\hline 2 & $\begin{array}{c}\text { Acetonitrile } \\
\text { (49) }\end{array}$ & $\begin{array}{l}1.38 \times 10^{-1} \\
2.76 \\
4.14 \\
5.52 \\
6.90\end{array}$ & $\begin{array}{l}3.70 \\
2.85 \\
2.47 \\
2.05 \\
0.55\end{array}$ & $\left.\begin{array}{l}0.63 \\
0.63 \\
0.57 \\
0.59 \\
0.55\end{array}\right\}$ & $0.59 \pm 0.04$ \\
\hline 3 & $\begin{array}{l}\text { Acetone } \\
\text { (64) }\end{array}$ & $\begin{array}{l}0.40 \times 10^{-1} \\
0.81 \\
1.21 \\
1.62 \\
2.02\end{array}$ & $\begin{array}{l}3.50 \\
2.41 \\
2.00 \\
1.64 \\
1.40\end{array}$ & $\left.\begin{array}{l}1.24 \\
1.31 \\
1.26 \\
1.27 \\
1.26\end{array}\right\}$ & $1.27 \pm 0.04$ \\
\hline 4 & $\begin{array}{l}\text { Dioxane } \\
\quad(77)\end{array}$ & $\begin{array}{l}1.52 \times 10^{-2} \\
3.04 \\
4.56 \\
6.08 \\
7.60\end{array}$ & $\begin{array}{l}3.92 \\
3.34 \\
2.66 \\
2.20 \\
1.96\end{array}$ & $\left.\begin{array}{l}1.50 \\
1.47 \\
1.47 \\
1.50 \\
1.48\end{array}\right\}$ & $1.48 \pm 0.02$ \\
\hline 5 & $\begin{array}{c}\text { Tetrahydrofuran } \\
(90)\end{array}$ & $\begin{array}{l}0.99 \times 10^{-2} \\
1.99 \\
2.69 \\
3.97 \\
4.97\end{array}$ & $\begin{array}{l}3.43 \\
2.63 \\
2.04 \\
1.73 \\
1.42\end{array}$ & $\left.\begin{array}{l}1.89 \\
1.85 \\
1.87 \\
1.85 \\
1.87\end{array}\right\}$ & $1.87 \pm 0.02$ \\
\hline 6 & $\begin{array}{l}\mathrm{N}, \mathrm{N} \text {-Dimethyl- } \\
\text { formamide } \\
(107)\end{array}$ & $\begin{array}{l}0.90 \times 10^{-8} \\
1.80 \\
2.69 \\
3.59 \\
4.49\end{array}$ & $\begin{array}{l}3.81 \\
3.02 \\
2.44 \\
2.07 \\
1.80\end{array}$ & $\left.\begin{array}{l}2.95 \\
2.88 \\
2.87 \\
2.85 \\
2.83\end{array}\right\}$ & $2.88 \pm 0.07$ \\
\hline 7 & $\begin{array}{l}\text { Dimethyl } \\
\text { sulfoxide } \\
\text { (141) }\end{array}$ & $\begin{array}{l}0.58 \times 10^{-8} \\
1.15 \\
1.73 \\
2.30 \\
2.88\end{array}$ & $\begin{array}{l}3.49 \\
2.55 \\
1.84 \\
1.41 \\
1.11\end{array}$ & 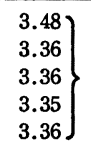 & $3.38 \pm 0.10$ \\
\hline 8 & $\begin{array}{l}\text { Pyridine } \\
\text { (168) }\end{array}$ & $\begin{array}{l}0.51 \times 10^{-3} \\
1.01 \\
1.52 \\
2.02 \\
2.53\end{array}$ & $\begin{array}{l}3.81 \\
2.87 \\
2.10 \\
1.63 \\
1.33\end{array}$ & $\left.\begin{array}{l}3.41 \\
3.32 \\
3.35 \\
3.34 \\
3.33\end{array}\right\}$ & $3.35 \pm 0.06$ \\
\hline 9 & $\begin{array}{l}\text { 2-Picoline } \\
\text { (183) }\end{array}$ & $\begin{array}{l}0.39 \times 10^{-8} \\
0.77 \\
1.16 \\
1.54 \\
1.93\end{array}$ & $\begin{array}{l}3.90 \\
2.66 \\
1.94 \\
1.43 \\
1.16\end{array}$ & $\left.\begin{array}{l}3.69 \\
3.70 \\
3.64 \\
3.62 \\
3.59\end{array}\right\}$ & $3.65 \pm 0.06$ \\
\hline 10 & $\begin{array}{c}\text { Triethyl amine } \\
\text { (238) }\end{array}$ & $\begin{array}{l}0.30 \times 10^{-8} \\
0.60 \\
0.90 \\
1.20 \\
1.50\end{array}$ & $\begin{array}{c}2.62 \\
0.06 \\
- \\
- \\
-\end{array}$ & $\left.\begin{array}{l}-8 \\
- \\
- \\
- \\
-\end{array}\right\}$ & -8) \\
\hline 11 & $\begin{array}{c}\text { Methanol } \\
(-)\end{array}$ & $\begin{array}{c}2.34 \times 10^{-2} \\
4.68 \\
7.02 \\
9.36 \\
11.7\end{array}$ & $\begin{array}{l}3.46 \\
2.46 \\
1.84 \\
1.45 \\
1.25\end{array}$ & $\left.\begin{array}{l}1.51 \\
1.52 \\
1.56 \\
1.57 \\
1.56\end{array}\right\}$ & $1.55 \pm 0.04$ \\
\hline
\end{tabular}

1) The apparent first order rate constant in eq. (2).

2) $K:$ The equibrium constant in eq. (4), $\mathrm{mol}^{-1}$.

3) The equibrium constant $K$ can not be estimated because of $c-y<0$.

4) Initial concentration : $\left[1_{m}\right] 3.08 \times 10^{-4} \mathrm{~mol} / l$, Dichloroacetic acid $8.86 \times 10^{-4} \mathrm{~mol} / l$. 
に求めた。

[平衡定数 $K$ の求め方]

ベンゼン溶媒中で

$$
\mathrm{RCO}_{2} \mathrm{H}+: \mathrm{XS} \stackrel{K}{\rightleftarrows} \mathrm{RCO}_{2} \mathrm{H} \cdots \mathrm{XS}
$$

$\mathrm{R}: \mathrm{Cl}_{2} \mathrm{CH}$

$\mathrm{XS}$ : 溶媒分子

$$
\mathrm{X}: \mathrm{O} \text { (酸素), } \mathrm{N} \text { (窒素) }
$$

なる平衡を考える。ここで, [4] は水素結合錯体を示 す。 [4] のジクロ口酢酸は溶媒分子 SX との水素結合 のため酸度が低下しているから， $\left[1_{m}\right]$ の脱離反応は加 えた溶媒分子と相互作用しない酸だけが関与するものと 仮定する。まず，溶媒分子を添加しない場合の $k_{1, a} v s$. $\left[\mathrm{Cl}_{2} \mathrm{CHCO}_{2} \mathrm{H}\right]_{0}$ の プロット (Fig.-3，曲線 $\mathrm{OZ}$ ) をと る。 $\left[\mathrm{Cl}_{2} \mathrm{CHCO}_{2} \mathrm{H}\right]_{0}=b$ (点 $\mathrm{C}$ ), $[\mathrm{SX}]_{0}=0$ のときの 1 次速度定数を $k_{1,0}$ (点 $\mathrm{A}$ ), $\left[\mathrm{Cl}_{2} \mathrm{CHCO}_{2} \mathrm{H}\right]_{0}=a,[\mathrm{SX}]_{0}$ $=c$ のときの 1 次速度定数を $k_{1, c}$ (点 $\mathrm{P}$ ) とすると, $\overline{\mathrm{OC}}=b, \overline{\mathrm{OA}}=k_{1,0}, \overline{\mathrm{OP}}=k_{1, c}$ となる。点 $\mathrm{P}$ より $\mathrm{OX} に$ 平行線を引き曲線 $\mathrm{OZ}$ との交点を $\mathrm{Q}$ とする。点 $\mathrm{Q}$ より OX に垂線を下ろしその交点を $\mathrm{R}$ とする。式 (3) によっ て消費されたジクロ口酢酸の濃度, つまり水素結合錯体 の濃度を $y$ とすると, $\overline{\mathrm{RC}}=y$ となり, 平衡定数 $K$ は 次式で表される。

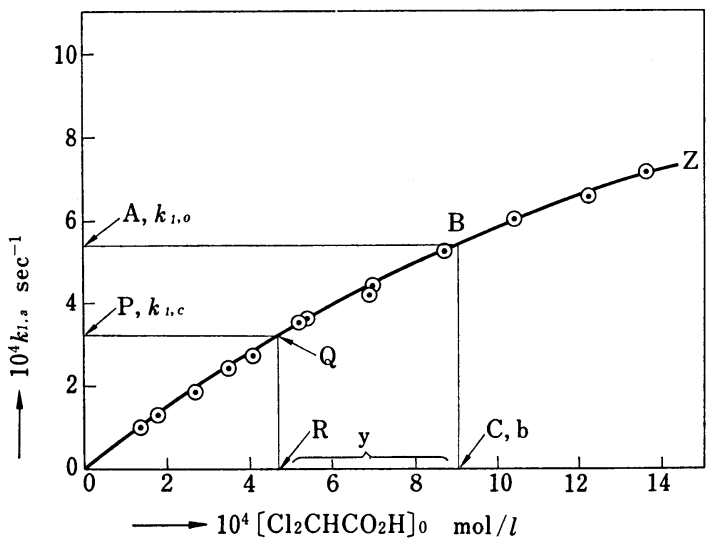

Curve OZ; A plot of $\log k_{1, a}$ vs. $\left[\mathrm{Cl}_{2} \mathrm{CHCO}_{2} \mathrm{H}\right]_{0}$ when $[\mathrm{SX}]_{0}=0$.

$\overline{\mathrm{OA}}=k_{1,0}$; The apparent first order rate constant when $\left[\mathrm{Cl}_{2} \mathrm{CHCO}_{2} \mathrm{H}\right]_{0}=b$ and $[\mathrm{SX}]_{0}=0$.

$\overline{\mathrm{OP}}=k_{1, c}$; The apparent first order rate constant when $\left[\mathrm{Cl}_{2} \mathrm{CHCO}_{2} \mathrm{H}\right]_{0}=b$ and $[\mathrm{SX}]_{0}=c$.

$\overline{\mathrm{OC}}=b$; The initial concentration of dichloroacetic acid.

$\overline{\mathrm{RC}}=\boldsymbol{y} \quad$; The concentration of the hydrogen bonding complex [4] in eq. (3) when $\left[\mathrm{Cl}_{2} \mathrm{CHCO}_{2} \mathrm{H}\right]_{0}$ $=b$ and $[\mathrm{SX}]_{0}=c$.

Fig.-3 A plot of $k_{1, a}$ vs. $\left[\mathrm{Cl}_{2} \mathrm{CHCO}_{2} \mathrm{H}\right]_{0}$ for the dichloroacetic acid catalyzed elimination reaction of $[1 \mathrm{~m}]$ in benzene at $40^{\circ} \mathrm{C}$.

$$
K=\frac{y}{(b-y)(c-y)}
$$

上述の方法で求めた平衡定数 $K$ の対数值は Table2 に併記した。 $K$ が一定であることは，上記の仮定が 正しいことを示す。Fig.-4 に $\log K v s . \Delta \nu_{D}$ の相関性 を示した。添加溶媒がニトリル，カルボニル，エーテ ル, アミド, スルホキシドの場合は, 溶媒の電子供与度 が大きくなるにつれて $\log K$ の值が直線的に増加する ことがわかる。電子供与度は $\mathrm{CH}_{3} \mathrm{OD}$ の重プロトンの 溶媒によるシフト值, つまり, 重プロトンの受容度であ るから妥当な結果である。Fig.-4 で直線関係（直線自 由エネルギー関係）が得られたことは極めて重要な結果 である。このことは，溶媒分子 SX の重プロトンに対 する受容度とジクロロ酶酸のプロトンに対する受容度が 平行関係にあることを意味する。したがって，他のプロ トン供与体の場合にもこの関係が拡張される。

また，この直線関係を用いてメタノールの酸素原子の 電子供与度（～塩基性）を評価すると， $\log K=1.55$ で あるからジオキサンつまりエーテル類と同じ強さをもつ ことがわかる。カルボニル酸素の電子供与度をケトンと アルデヒド類について比較すると，アセトンが $\Delta \nu_{D}=64$ $\mathrm{cm}^{-1}$ で，アセトアルデヒドが $\Delta \nu_{D}=79 \mathrm{~cm}^{-1}$ であるか ら,メタノールの $\log K$ の值は妥当な值である。メタ ノールと同様にエタノール， $n$-ブタノール， $n$-プロパ ノールの場合の $\log K$ を求めると $1.55 \sim 1.62$ とほぼ

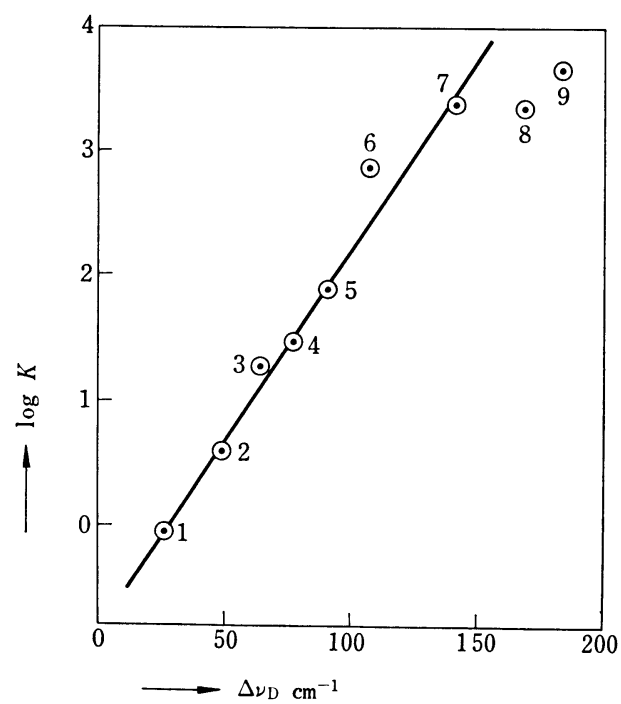

$K\left(\mathrm{~mol}^{-1}\right)$; The equilibrium constant of the formation of hydrogen bonding complex [4] in benzene at $40^{\circ} \mathrm{C}$.

Added solvents, SX; $1:$ Anisol, $2:$ Acetonitrile, 3 : Acetone, $4:$ Dioxane, $5:$ Tetrahydrofuran, $6:$ N, N-Dimethylformamide, 7 : Dimethyl sulfoxide, 8 : Pyridine, $9: 2$-Picoline.

Fig.-4 A plot of $\log K v s$. $\Delta \nu_{D}$ (the electron donability) of SX. 
メタノールと同じ值が得られた。このことは, エーテル 類の場合（電子供与度）と同様"), アルコール酸素の水 素結合能力に及ぼすアルキル基の効果が小さいことを示 している。

添加溶媒 SX がトリエチルアミンの場合, 平衡定数 $K$ を求めることはできなかった (Table-2)。この場合, 加えたトリエチルアミンの濃度が $3,6 \times 10^{-4} \mathrm{~mol} / l$ の とき,消費したジクロロ酶酸の濃度が $5.20,8.09 \times 10^{-4}$ $\mathrm{mol} / l$ であり $c-y<0$ となる。つまり，加えたアミ ンよりも多くのジクロ口酢酸が消費された。このこと は, 添加溶媒が強いアミンの場合, アミン1分子に対し て 1 分子以上のジクロロ酢酸が作用することを示唆して いる。

\section{3 トルエン溶媒中におけるジクロロ酢酸とアミン との相互作用}

前述のように塩基性の高いアミンを添加すると $c-x$ $<0$ となり平衡定数 $K$ を求めをことができなかった。 そこで, 基質として $\left[1_{p}\right]$ を選び, トルエン溶媒中でジ クロロ酶酸触媒による脱離反応の速度に及ぼすいくつか のアミンの効果について検討した $\left(40^{\circ} \mathrm{C}\right)$ 。これらの場 合, 平衡定数 $K$ が求まらないものがあるから次の方法 で図式的に $k_{1,0} / 2$ なるアミンの濃度 $[\mathrm{N}]_{1 / 2}$ を求めた。 ここで, $k_{1,0}$ はアミンを添加しない場合の見かけの 1 次 速度定数である。

ジクロロ酶酸の初濃度を $8.63 \times 10^{-4} \mathrm{~mol} / l,\left[1_{p}\right]$ の 初濃度を $3.00 \times 10^{-4} \mathrm{~mol} / l$ で一定に保ち, 添加するア ミンの濃度を変化させて $k_{1, a} v s .[\mathrm{N}]_{0}$ のプロットをと る(曲線 $\mathrm{S})$ 。ここで $[\mathrm{N}]$ 。 は添加したアミン濃度を示 す。 $[\mathrm{N}]_{0}=0$ のとき, $k_{1, a}=k_{1,0}=4.10 \times 10^{-4} \mathrm{sec}^{-1}$ であ るから $k_{1,0} / 2=2.05 \times 10^{-4} \mathrm{sec}^{-1}$ の点 $\mathrm{A}$ より横軸に平行 線を引き曲線 $\mathrm{S}$ との交点を $\mathrm{B}$ とする。点 $\mathrm{B}$ より横軸に垂 線を下ろしその交点を $\mathrm{C}$ とすと，その横軸の目盛の值 が $[N]_{1 / 2}$ となる。Fig.-5 に代表例として 2-ピコリン （曲線 $S_{1}$ ) とトリエチルアミン（曲線 $\mathrm{S}_{2}$ ) の場合を示 した。これらの場合， $[\mathrm{N}]_{1 / 2}$ の值はおのおの，7.40， $2.66 \times 10^{-4} \mathrm{~mol} / l$ であった。上述の方法で求めた $[\mathrm{N}]_{1 / 2}$ の值は Table-3 に示す通りである。

用いたアミンの電子供与度 $\Delta \nu_{D}$ の值が知られていな いものがあるので, 水中におけるアミンの $p K_{B H}$ の值 との相関性について調べた。Fig.-6に $\log [\mathrm{N}]_{1 / 2}$ vs. $p K_{B H}$ のプロットを示した。アミンの塩基性が高くな る程, $[\mathrm{N}]_{1 / 2}$ の值が小さくなり, $p K_{B H}$ が 5 11 のと ころでは直線性が成立している。

一般に,アミンと強酸との反応は第四級塩 (イオン対) を生ずる。四級塩は種々の溶媒中で, 緊密イオン対せ溶 媒介在イオン対を遊離イオンの平衡を通して解離するこ とが知られている ${ }^{8)}$ 。本研究の場合，溶媒がベンゼンや トルエンと極性が非常に低いからジクロロ酢酸とアミン

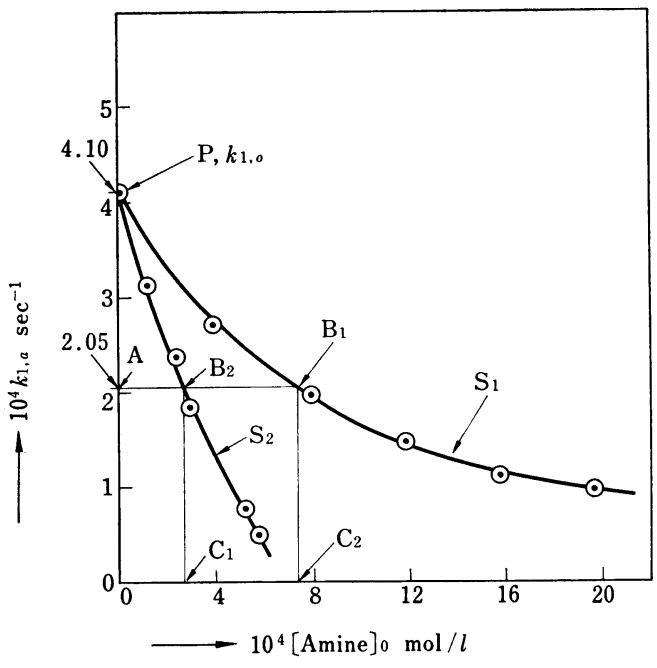

$[\mathrm{N}]_{0}$; The initial concentration of amines, $\mathrm{mol} / l$.

Initial concentrations; Dichloroacetic acid $8.63 \times 10^{-4}$ $\mathrm{mol} / l,\left[1_{p}\right] 3.00 \times 10^{-4} \mathrm{~mol} / l$.

Amines; $\mathrm{S}_{\mathbf{1}}$ 2-Picoline, $\mathrm{S}_{\mathbf{2}}$ Triethyl amine.

$\overline{\mathrm{OP}}=k_{1,0}=4.10 \times 10^{-4} \mathrm{sec}^{-1}$; The apparent first order rate constant in eq. (2), when $[\text { amine }]_{0}=0 \mathrm{~mol} / l$.

$\overline{\mathrm{OA}}=k_{1,0} / 2=2.05 \times 10^{-4} \mathrm{sec}^{-1}$;

$[\mathrm{N}]_{1 / 2}$; The concentration of the added amines at $k_{1, a}$ $=k_{1,0} / 2$.

$\overline{\mathrm{OC}_{1}}=[2-\mathrm{Picoline}]_{1 / 2}=7.40 \times 10^{-4} \mathrm{~mol} / \mathrm{l}$.

$\overline{\mathrm{OC}_{2}}=[\text { Triethyl amine }]_{1 / 2}=2.66 \times 10^{-4} \mathrm{~mol} / l$.

Fig.-5 The effect of amines on the dichloroacetic acid catalyzed elimination reaction of $1-(p-$ nitrophenyl)-2-(2-quinolyl)ethyl acetate $\left[1_{p}\right]$ in toluene at $40^{\circ} \mathrm{C}$ : Plots of $k_{1, a} v s$. $[\mathrm{N}]_{0}$.

Table-3 The values of $[\mathrm{N}]_{1 / 2}, \log K$ and $p K_{B H}$.

\begin{tabular}{|c|c|c|c|}
\hline Anine & $p K_{B H^{1)}}$ & {$[N]_{1 / 2}{ }^{2)}$} & $\log K^{8)}$ \\
\hline$o$-Toluidine & 4.44 & $0.58 \times 10^{-1}$ & 1.35 \\
\hline 3-Picoline & 5.68 & \multirow{7}{*}{$\times 10^{-4}$} & 3.58 \\
\hline 2-Picoline & 5.97 & & 3.72 \\
\hline 4-Picoline & 6.02 & & 3.37 \\
\hline Lutidine & 6.99 & & - \\
\hline Morpholine & 8.33 & & - \\
\hline Triethyl amine & 10.78 & & -0 \\
\hline Diisobutyl amine & 10.91 & & -6 \\
\hline Diisopropyl amine & 10.96 & 3.15 & -4) \\
\hline
\end{tabular}

1) The values in water at $20 \sim 25^{\circ} \mathrm{C}$.

2) The concentration of added amine at $k_{1, a}=k_{1,0} / 2$, $\mathrm{mol} / l$.

3) The equilibrium constant in eq. (4), $K, \mathrm{~mol}^{-1}$.

4) $K$ can not be estimated because of $c-y<0$.

の第四級塩の緊密イオン対 [5] が存在する。塩基性の高 いアミン 1 分子が， 1 分子以上のジクロロ酢酸を消費す るのは, この緊密イオン対 [5] の対陰イオン, ジクロロ アセタートアニオンにさらにもら一分子のジクロロ酢酸 


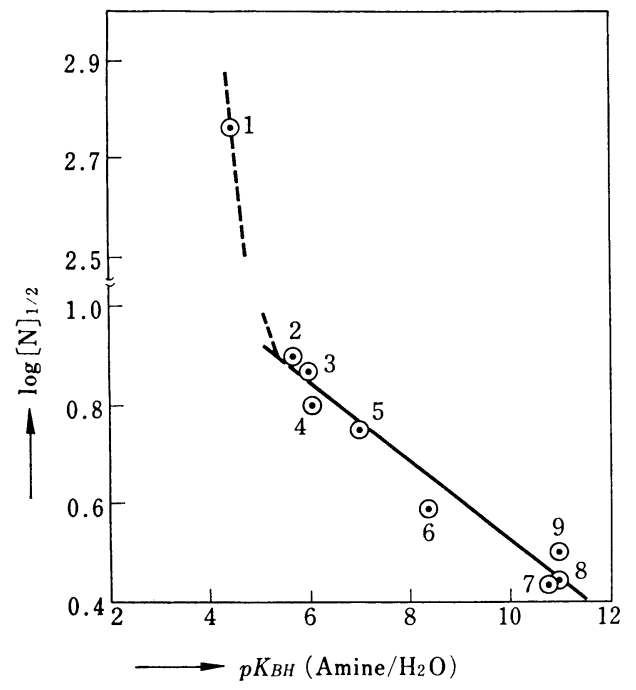

$[\mathrm{N}]_{1 / 2}$; The concentration of the added amines at $k_{1, a}$ $=k_{1,0} / 2, \mathrm{~mol} / l$, in toluene at $40^{\circ} \mathrm{C}$. From the data in Table-3.

$p K_{B H}$; The dissociation constant of protonated amines in water at $20 \sim 25^{\circ} \mathrm{C}$.

Amines ; $1: o$-Toluidine, 2:3-Picoline, 3:2-Picoline, $4: 4$-Picoline, $5:$ Lutidine, $6:$ Morpholine, 7 : Triethyl amine, 8 : Diisobuthylamine, 9 : Diisopropyl amine.

Fig.-6 A plot of $\log [\mathrm{N}]_{1 / 2}$ in toluene vs. $p K_{B H}$ in water.

\section{Scheme-2}

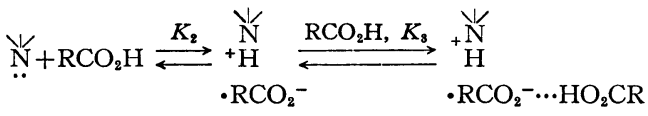

$$
\begin{aligned}
& \text { [5] }
\end{aligned}
$$

が作用（水素結合）して $[6]$ を生ずるためであろう。こ のことは, ベンゼン溶媒中における $\left[1_{p}\right]$ のカルボン酸 触媒による脱離反応でカルボン酸の濃度が過剩になると 反応速度が低下することと相応している4)。カルボキシ ラートアニオンとカルボン酸との水素結合が知られてい る $^{9)}$ こから，[6] の形の水素結合錯体は妥当なものと 考えられる。また，溶媒介在イオン対は対陰イオンある いは対陽イオンに溶媒が作用（溶媒和または水素結合）
したものであるから $[6]$ の形は溶媒介在イオン対の一種 と考えられる。

加えたアミンの塩基性が高くなるほど， $[\mathrm{N}]_{1 / 2}$ の值 が小さくなるのはジクロロ酢酸のアミン窒素へのプロト ン化の段階（ $K_{2}$ の項）に大きく効くためである。 $o-卜$ ルイジンの場合, $p K_{B H}$ の值から予想されるより大き な $[\mathrm{N}]_{1 / 2}$ の值を示すのは, 第一アミンのためのプロト ンによる反発によるか， $o$-置換基の立体障害のための両 方が考えられるが得られたデータからは区別できない。

非極性溶媒中で 1 分子のアミンに対して 1 分子以上の カルボン酸が作用することは，この種の溶媒中でアミン あるいはカルボン酸の解離定数や相対酸度を求めるさい 充分注意を要することを示唆している。

最後に, 本研究で求めた平衡定数 $K$ および $[\mathrm{N}]_{1 / 2}$ の值はジクロロ酢酸の [1]のキノリン窒素へのプロトン 化と溶媒分子の酸素, 窒素原子上の孤立電子対への相互 作用（プロトン化あるいは水素結合）との相対的な值で ある。

中部化学関係学協会支部連合秋季大会の一般研究発表会にて 講演, 1974 年 10 月, 名古屋。

（昭和 49 年 10 月 31 日受理）

\section{文献}

1）平田,今枝, 福住, 日本化学会第 26 春季年会, 平塚 (1972)

2) T. Kagiya et al., Bull, Chem. Soc. Japan, 41, 767, 773, 779 (1968)

3) R.N. Icke, C.E. Redemann, B.B. Wisegarver, G.A. Alles, “Organic Syntheses", Coll. Vol. III, p. 644 (1955) John Wiley \& Sons, Inc., New York, N.Y.,

4) 平田, 福住, 日化, 34 (10), 1929 (1974)

5) 浅原編, 妹尾, 新井, “有機化学反応に打ける溶媒効果” p. 68 (1970), 産業図書, 東京

6) H. Sterk, Monatsh Chem., 99, 457 (1968); J.T. Harris Jr., M.E. Webbs, J. Amer. Chem. Soc., 76, 1419 (1954)

7) D.J. Cram et al., J. Amer. Chem. Soc., 81, 5740, $5754,5750,5767,5774$ (1959)

8) E.M. Kosower, J. Amer. Chem. Soc., 80, 3253 (1958)

9) L. Eberson, "The chemistry of carboxylic acids and esters” ed., by S. Patai, p. 239 (1969) John Wiley \& Sons Ltd., London-New York-Sydney-Toronto,

10) J. Riddick, W. Bunger, “Organic Solvents" 3rd ed., (1970) Wiley-Interscience, New York-LondonSydney-Toronto 